\title{
Recombinant Flt3 Ligand
}

National Cancer Institute

\section{Source}

National Cancer Institute. Recombinant Flt3 Ligand. NCI Thesaurus. Code C1714.

A recombinant therapeutic agent which is chemically identical to or similar to the endogenous cytokine Flt3. Flt3 lig and binds to the Flt3 tyrosine kinase receptor and, synergistically with other growth factors, stimulates the proliferation and mobilization of bone marrow precursor cells, including CD34+ cells, and dendritic cells. When proteolytically cleaved, the transmembrane isoform of Flt3 ligand generates the soluble form soluble Flt3 ligand, which is also biologically active. 